\title{
Wpływ stanu zachowania materiału konstrukcyjnego na nośność zabytkowych drewnianych słupów, w żuławskich domach podcieniowych, z XVIII i XIX wieku
}

\author{
Tomasz Zybala
}

\author{
Katedra Historii, Teorii Architektury i Konserwacji Zabytków, Wydziat Architektury, \\ Politechnika Gdańska oraz \\ Wydziat Architektury i Wzornictwa, Akademia Sztuk Pięknych w Gdańsku oraz \\ Wydziat Architektury, Sopocka Szkoła Wyższa. \\ e-mail:t.zybala7@gmail.com
}

Streszczenie: Powstało wiele opracowań dotyczących zagadnień architektonicznych domów podcieniowych na Żuławach, ale brak na ten temat publikacji dotyczących problematyki techniczno-konserwatorskiej. Niniejszy artykuł jest fragmentem badań prowadzonych obecnie przez autora. Jest pierwszą próbą wykonania analizy statycznowytrzymałościowej wybranych, zabytkowych drewnianych podcieni z obszaru Delty Wisły, wraz z opisem stanu zachowania. W tekście zawarto główne cechy wytrzymałościowe drewna, zasady obliczania nośności słupów wg PN EN 1995-1-1 oraz PN-53/B03150. Obliczono przybliżony ciężar przenoszony przez zabytkowe podcienia. W pracy ujęto opis występowania formy i zakresu terytorialnego budownictwa podcieniowego w Polsce. Wyjaśniono cel stosowania tego rozwiązania w budynkach. Przedstawiono rodzaje konstrukcji słupów oraz typologię i historyczny rozwój domu podcieniowego na Żuławach Wiślanych, z jego głównymi cechami charakterystycznymi.

Słowa kluczowe: domy podcieniowe, architektura drewniana, nośność słupa drewnianego.

\section{Wstęp}

Budownictwo podcieniowe stanowiło powszechny element tradycyjnej, drewnianej zabudowy na terenach dawnej Polski oraz ziem sąsiednich: Śląska, Pomorza i Prus. Głównym celem stosowania podcieni w konstrukcji budynku, podobnie jak werand, ganków i sobót przy kościołach było stworzenie dodatkowej zadaszonej powierzchni przy budynku. Miała ona służyć osłonie drzwi wejściowych przed deszczem. Stanowiła też przestrzeń do odpoczynku. Podcienia miewały charakter reprezentacyjny, świadczący o statusie majątkowym właściciela budynku. Wyróżniały się wysokim poziomem ciesielskim i artystycznym. Drewniane domy podcieniowe występujące w Polsce różniły się między sobą wielkością, bryłą, rozplanowaniem wnętrz, konstrukcją. Odzwierciedlały styl życia i status materialny członków lokalnej społeczności, przynależność etniczną, poziomu rozwoju ciesielstwa, technik budownictwa drewnianego w danym okresie [1]. Podcienia posiadały także budynki użyteczności publicznej - kościoły, karczmy, ratusze oraz obiekty przemysłowe i gospodarcze, takie jak kuźnie i spichrze. Wiejskie domy podcieniowe były inspirowane budownictwem miejskim i dworskim. Wykonywano je w konstrukcji murowanej, drewnianej lub mieszanej. Sytuowano je wzdłuż ścian podłużnych lub szczytowych, na całej długości lub na jej części. Występowały także inne formy jak podcień narożny, wnękowy. 
Podcienia sytuowano w przyziemiu, ale bywały również dwukondygnacyjne [2]. Słupy podcieni są elementami drewnianymi, murowanymi bądź też żeliwnymi. Żuławskie podcienia analizowane w artykule są drewnianymi elementami konstrukcyjnymi przenoszącymi obciążenia od ryzalitu i dachu na fundament. Słupy w górnej części osadzone są w belce oczepowej ramy piętrowej wystawki. Czasami słupom nadawano formę kolumn, o różnej stylistyce: jońskiej lub toskańskiej. W XVII wieku słupy są dość krępe, ich proporcje wynoszą w najstarszych obiektach, w przybliżeniu 1:6, w późniejszym okresie, w XVIII wieku stosunek ten równa się 1:8, za to obiekty z drugiej połowy XIX wieku osiągają już $1: 9,5^{1}$ [3]. Żuławskie domy podcieniowe są obiektem zainteresowań badaczy od XIX wieku. Do 1945 byli to przede wszystkim Otto Kloeppl ${ }^{2}$ i Bernard Schmidt ${ }^{3}$. Wśród polskich powojennych badaczy należy wymienić Jerzego Stankiewicza ${ }^{4}$ i ostatnio Martę Koperską-Kośmicką autorkę rozprawy doktorskiej, obronionej na Wydziale Architektury Politechniki Gdańskiej. Żuławskie domy podcieniowe stanowiły najczęściej pole badawcze dla historyków architektury. Dotychczasowe opracowania koncentrowały się głównie na rozwoju, przekształceniu formy i funkcji budynków. Problematyka technicznokonserwatorska w szerszym zakresie dla większej liczby zabytkowych obiektów nie została nigdzie omówiona. Istnieją owszem pojedyncze prace, opinie, projekty i ekspertyzy, które jednak odnoszą się tylko do pojedynczych obiektów. Nie ma za to zbiorczych opracowań dla większej grupy domów podcieniowych. Brak analiz dotyczących ustrojów budowlanych, mechaniki konstrukcji w warunkach eksploatacji, ingerencji technicznych (remontów) i ich wpływu na zabytkową strukturę, jak też oceny prawidłowości prac remontowych z punktu widzenia współczesnych zasad konserwacji zabytków. W artykule użyto ogólnego terminu „słup”, co jest usprawiedliwione tematyką tekstu. Nie ma to znaczenia z punktu widzenia pracy elementów w konstrukcji budynku. Celem artykułu jest wykazanie iż mimo uszkodzeń i wieku, autentyczne drewniane słupy żuławskich domów podcieniowych mogą być ponownie wykorzystane przy remoncie lub modernizacji obiektu.

\section{2. Żuławskie domy podcieniowe - historia i rozwój formy}

Żuławskie domy podcieniowe są charakterystyczne dla historycznej architektury Delty Wisły. O powszechności występowania tego typu obiektów na Żuławach świadczą mapy Suchego Dębu i Myszewa z XVII wieku (ryc. nr 1).

Stanowią dowód ciągłości tradycji budownictwa podcieniowego. Widać na nich ciągi domów podcieniowych wzdłuż wiejskiej ulicy [4]. Na mapie Berndta z 1603r. pokazującej tereny gdańskiego Młodego Miasta widać prawdopodobnie także obiekty tego typu [5]. Najstarszą dostępną publikacją opisującą budownictwo żuławskie jest spis zabytków Johanna Heisego z lat 1884-1887 [6]. Praca skupia się głównie na obiektach średniowiecznych (zamki i budowle sakralne), ale w jednym z podrozdziałów można znaleźć ilustrację pokazującą detal podcienia domu w Steblewie, który istnieje po dzień dzisiejszy. Przed drugą wojną światową przeprowadzono próby wznowienia dawnych tradycji żuławskiego budownictwa regionalnego. Przykładem jest dom ludowy w Zwierznie, z 1938 roku, obecnie szkoła podstawowa. Systematykę domów podcieniowych Delty Wisły opracował w latach 1920 Otto Kloeppel. Wyróżnił on trzy podstawowe typy budynków:

\footnotetext{
${ }^{1}$ Marta Koperska - Kośmicka w swojej rozprawie doktorskiej opisała szczegółowo systematykę i historyczny rozwój formy słupów i kolumn żuławskich podcieni w rozdziale: 6.1 Stupy i kolumny podcienia.

${ }^{2}$ Otto Kloeppel (1873-1942) architekt, konserwator, profesor i rektor Technische Hochschule der Freien Stadt Danzig.

${ }^{3}$ Bernard Schmidt (1872-1947) konserwator zabytków prowincji Prusy Zachodnie.

${ }^{4}$ Jerzy Stankiewicz (1923-1994) absolwent i profesor Wydziału Architektury Politechniki Gdańskiej.
} 


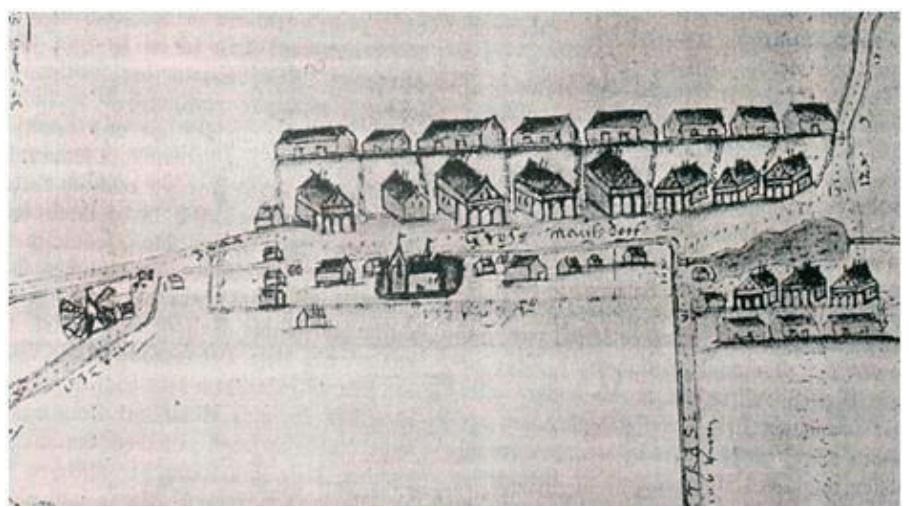

Ryc. 1. Wieś Myszewo w XVII wieku, widoczne domy podcieniowe wzdłuż ulicy. Źródło: [4]

I) Dom z podcieniem szczytowym. Jest to najstarsza forma rozwoju, powszechna do XVII wieku (ryc. nr 2).

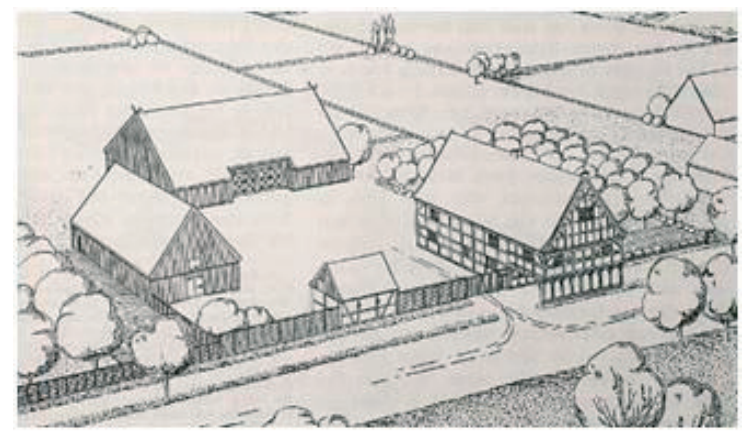

Ryc. 2. Dom podcieniowy - typ I. Źródło: [4]

Obiekty na planie prostokąta, z sienią bez bogatego wystroju. Piętro ulokowane na całym rzucie domu. Liczba słupów podcienia do dziewięciu. Domy tego typu zachowały się w Gdańsku-Lipcach (fot. nr 1), Kleciu i Rozgarcie.

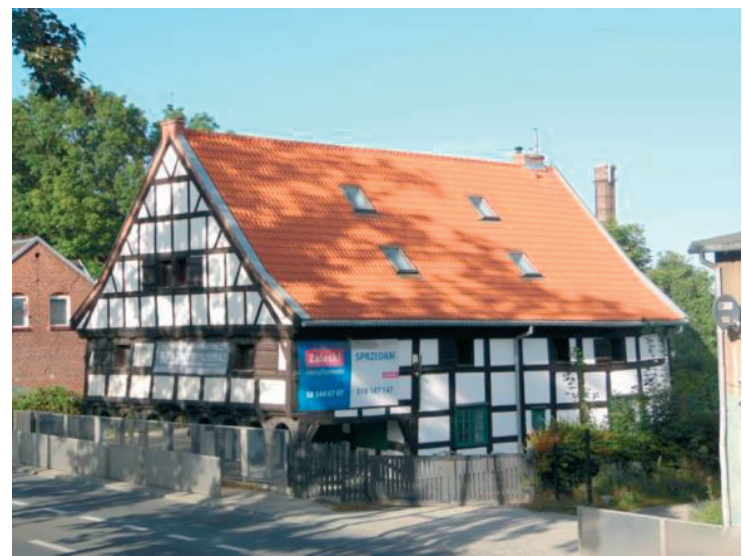

Fot. 1. Dom podcieniowy w Gdańsku Lipcach, typ I. (fot. Autor) 
II) Dom z podcieniem szczytowym, z dobudowanym skrzydłem bocznym. Rozwój nastąpił w XVII wieku. Domy posiadały dwukondygnacyjną sień, z której dostępna była większość pomieszczeń. W dobudowanym skrzydle znajdywały się pomieszczenia mieszkalne, czarna kuchnia, izba reprezentacyjna. Piętro usytuowano nad całą powierzchnią budynku, duża liczba słupów w podcieniu (ryc. nr 3). Zachowanymi przykładami są między innymi domy w Trutnowach (fot. nr 2) i Miłocinie.

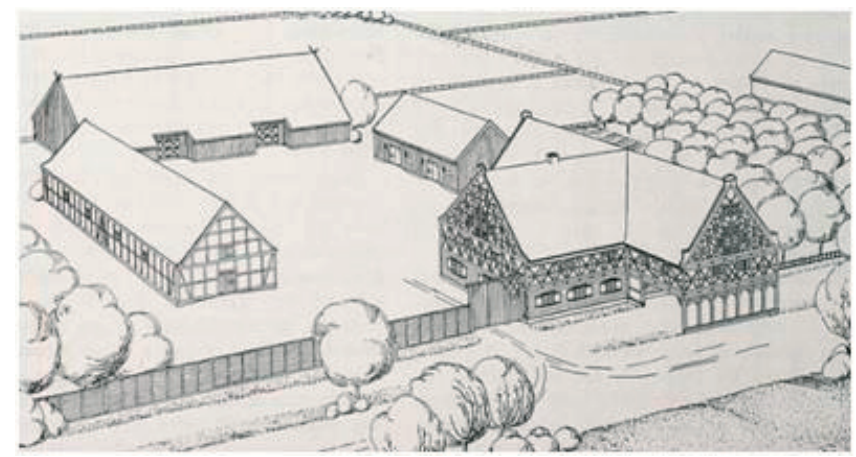

Ryc. 3. Dom podcieniowy - typ II. Źródło: [4]

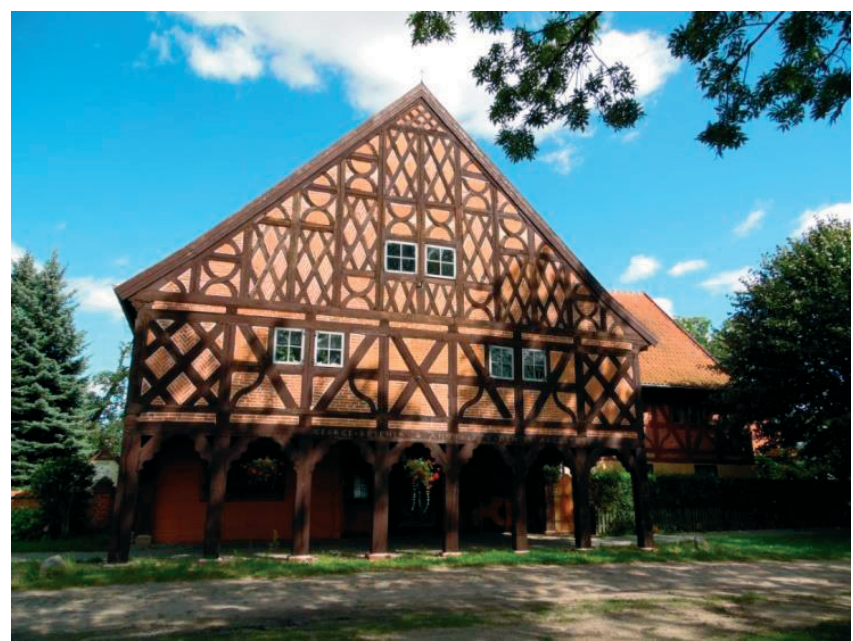

Fot. 2. Dom podcieniowy w Trutnowy, typ II. (fot. Autor)

III) Dom z centralnym ryzalitem podcieniowym (wystawką) - najpóźniejsza forma rozwoju, ukształtowała się w drugiej połowie XVIII wieku. Zanikło skrzydło boczne, piętro usytuowane jest tylko w ryzalicie nad podcieniem. Liczbę słupów zredukowano do sześciu lub czterech. Głowice słupów otrzymywały stylizację jońską lub toskańską. Konstrukcyjne miecze zastąpiły drewniane ozdoby reliefowe. Bogato dekorowane szkieletowe szczyty przyjmują postać regularnych krat, które w późniejszym okresie zostają odeskowane (ryc. $\mathrm{nr}$ 4).

W połowie XIX wieku dochodzi do spłycenia głębokości ryzalitu, przestaje on pełnić funkcję gospodarczą, jest już tylko historycznym elementem ozdobnym, pełniącym rolę werandy [7] (fot $\mathrm{nr} 3)$. 


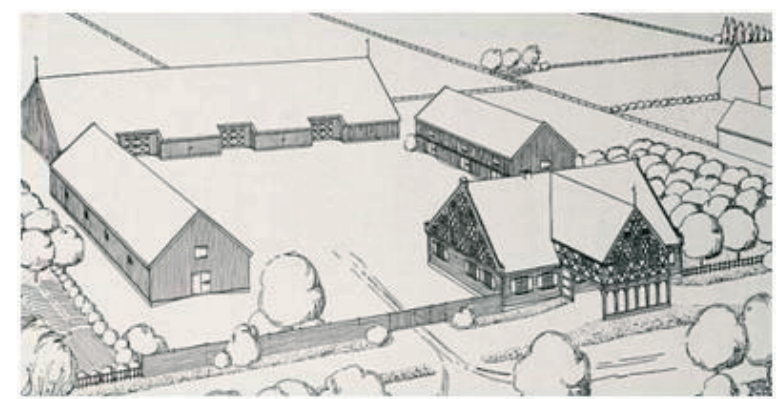

Ryc. 4. Dom podcieniowy - typ III. Źródło: [4]

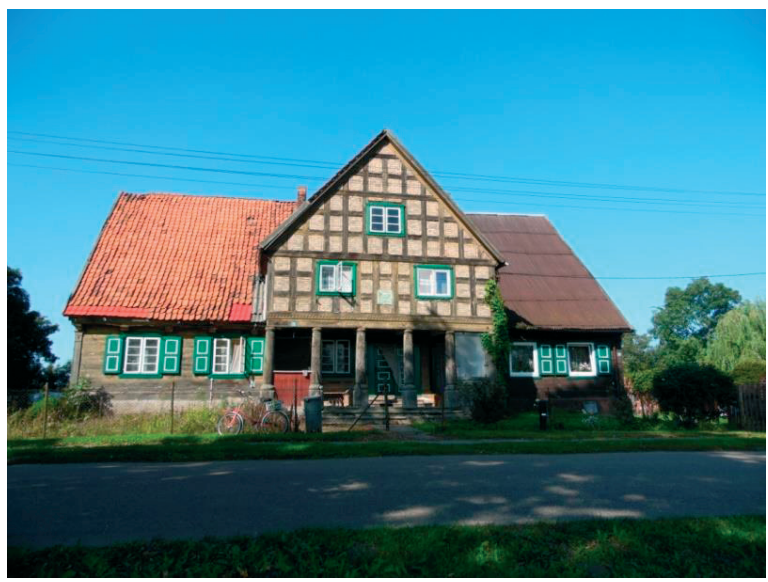

Fot. 3. Dom podcieniowy w Gniazdowie, typ III. (fot. Autor)

Najstarszy dom podcieniowy w Polsce znajduje się w Gdańsku Lipcach; reprezentuje typ I. Został zbudowany około 1600 roku. Jest to dom założony na planie prostokąta, o prostej bryle, zbudowany w konstrukcji szkieletowej, z dziewięciosłupowym podcieniem szczytowym. Swoją formą nawiązuje do gotyckich tradycji domów mieszkalnych. Kubatura całego obiektu wynosi ok. $2500 \mathrm{~m}^{3}$ [8]. Nie jest znana dokładna liczba istniejących w przeszłości domów podcieniowych na Żuławach. W ciągu XX wieku z obszaru Delty Wisły zniknęło 52\% domów. Proces ich niszczenia do 1945 r. wynikał z naturalnych procesów eksploatacji budynków drewnianych. Po II wojnie światowej proces degradacji zabytków nasilił się. Główną przyczyną tego zjawiska były procesy społeczno-gospodarcze w Polsce. W drugiej połowie lat czterdziestych nastąpiła całkowita wymiana ludności. Spowodowało to przerwanie ciągłości kulturowej i kilkusetletniej tradycji gospodarowania na trudnych zalewowych terenach Żuław. Domy podcieniowe pierwotnie miały jednego właściciela, który zarządzał całym gospodarstwem. Po wojnie w jednym obiekcie mieszkało często kilka rodzin wysiedleńców, którzy nie związani z nowym miejscem nie poczuwali się do odpowiedzialności za stan domu. Niejednokrotnie dochodziło do sytuacji kiedy lokatorzy celowo niszczyli obiekty aby szybciej zmienić miejsce zamieszkania. W świadomości nowych polskich mieszkańców i administracji, domy podcieniowe były jedną z pozostałości niemieckiego osadnictwa na tych terenach. Mimo objęcia niektórych obiektów prawną ochroną, poprzez wpisanie obiektów do rejestru zabytków, nie uchroniło ich to przed destrukcją. Głównymi przyczynami były niewystarczająca ilość środków na remonty oraz niewłaściwa eksploatacja [9]. 


\section{Wpływ właściwości drewna na nośność}

Żuławskie podcienie oparte są na słupach drewnianych. Nośność tych elementów konstrukcyjnych jest uzależniona od właściwości fizycznych i mechanicznych budulca, a także czasu i warunków eksploatacji. Struktura drewna przypomina wiązkę wzajemnie połączonych rurek równoległych do osi pnia. Powoduje to, że jest ono materiałem anizotropowym, wykazującym inne właściwości wzdłuż i w poprzek włókien [10]. W porównaniu ze stalą czy żelbetem drewno ma mniejszy ciężar objętościowy, powoduje to, że konstrukcję są lżejsze, łatwiejsze w transporcie i montażu. Zaletą drewna jest jego duża wytrzymałość na zginanie, ściskanie i rozciąganie, przy niewielkim ciężarze objętościowym. Drewno posiada dobre właściwości termiczne (niskie współczynniki przenikania ciepła). Jest materiałem trwałym, o czym świadczą zachowane, kilkusetletnie budynki. Wadami drewna są jego podatność na korozję biologiczną, palność, skurcz i pęcznienie pod wpływem zmian wilgotności [11]. Wzrost wilgotności drewna zmniejsza wytrzymałość na ściskanie i rozciąganie wzdłuż włókien, zwiększa podatność drewna na gnicie, pleśń i grzyby. Zmniejszenie wilgotności powoduje skurcz materiału, co może skutkować powstawaniem pęknięć. Z upływem czasu drewno zmienia swoje wymiary, dochodzi do zmniejszenia przekroju poprzecznego spowodowanego korozją biologiczną i skurczem. Powyższe procesy zmieniają pracę konstrukcji i sposób przenoszenia obciążeń. Modyfikacji mogą ulec połączenia sztywne elementów, a w ich miejsca mogą powstać połączenia przegubowe lub też dochodzi do ich uplastycznienia. Może to prowadzić do katastrofy budowlanej [12]. Głównymi zagrożeniami dla drewnianych słupów wolnostojących jest wilgoć, prowadząca do korozji biologicznej (rozwój grzybów i bakterii). Słupy narażone są również na atak owadów. Uszkodzenia te powstają głównie w dolnej części elementu, na styku z podłożem lub fundamentem. Istnieje również ryzyko powstania defektów mechanicznych, oderwania części powierzchni elementu na skutek uderzeń, wykonania otworów lub innych [13]. Słup jako element prętowy konstrukcji, w porównaniu do wymiarów przekroju poprzecznego: szerokości i wysokości posiada jeden wymiar dominujący długość. Słupy poddane są osiowemu ściskaniu, może to spowodować wygięcie osi pręta zwane wyboczeniem [14]. Konstrukcje budowlane poddane obciążeniom muszą znajdować się w stanie równowagi statecznej. Przy przekroczeniu wartości obciążenia krytycznego, dochodzi do wyboczenia elementu ściskanego, a zatem utraty stateczności elementu. Słup nie jest w stanie przenosić obciążeń i traci swoje właściwości konstrukcyjne. Utrata równowagi wynika z mimośrodowego przyłożenia siły ściskającej i niedoskonałej formy słupa, który zawsze posiada nawet minimalne deformacje geometryczne w swoim kształcie. Siła krytyczna powodująca wyboczenie jest zależna od sztywności i długości wyboczeniowej słupa. Obliczenia statyczne słupa mają na celu określenie wartości naprężeń ściskających w elemencie. [15].

\section{Stan zachowania drewnianych słupów żuławskich podcieni}

Do analizy statyczno-wytrzymałościowej wybrano najstarsze zachowane domy podcieniowe z obszaru Delty Wisły, które nie przeszły gruntownych remontów w ciągu ostatnich 70 lat. Obiekty przedstawione poniżej są wpisane do rejestru zabytków województwa pomorskiego [16] i województwa warmińsko mazurskiego [17]. Kolejnym kryterium decydującym o umieszczeniu w analizie danego obiektu, była zgoda właścicieli na wykonanie pomiarów konstrukcji podcienia. 
1. Bystrze nr 5/7 - dom podcieniowy z 1819 roku, typ III $^{5}$, słupy bogato rzeźbione, nie stwierdzono zawilgoceń, drewno w niewielkim stopniu zniszczone przez szkodniki, widoczne pojedyncze pęknięcia, słupy o przekroju kołowym, promień równy $17,5 \mathrm{~cm}$, wysokość $215 \mathrm{~cm}$, słupy usytuowane na murowanym cokole, ryzalit w złym stanie, budynek zamieszkały (fot. $\mathrm{nr}$ 4).

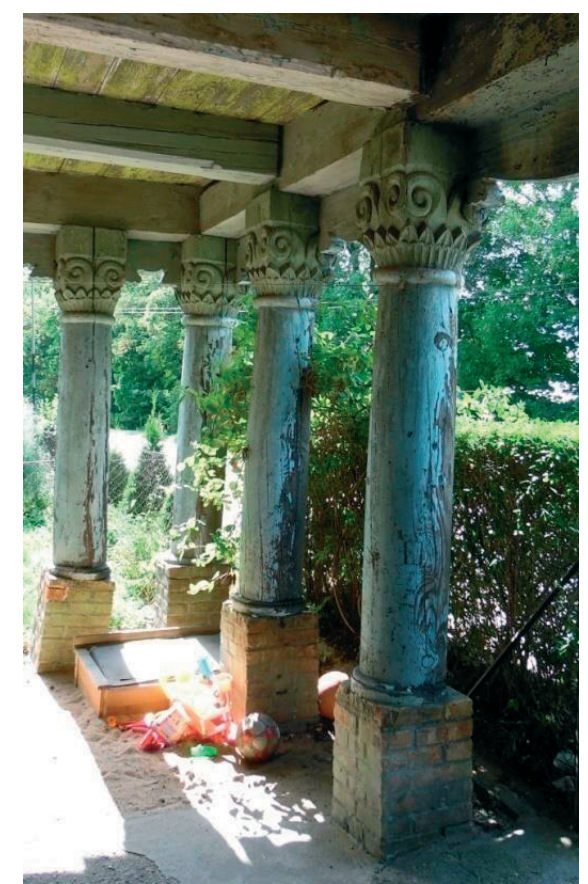

Fot. 4. Dom podcieniowy w Bystrzu. (fot. Autor)

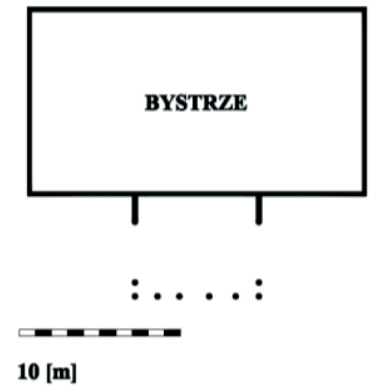

Rys. 1. Uproszczony rzut domu podcieniowego w Bystrzu. (opracowanie Autora)

2. Kępniewo nr 36 - dom podcieniowy z 1810, typ III, słupy zwieńczone formami antycznymi, nie posiadają śladów korozji biologicznej, drewno nie jest zniszczone przez szkodniki, widoczne drobne pęknięcia, słupy z odpryskami po malowaniu, przekrój kołowy o promieniu 14,5 cm, wysokość słupa drewnianego $250 \mathrm{~cm}$ podcień osadzony na murowanym kołowym cokole. Budynek zamieszkały przez kilka rodzin, obecnie żaden z właścicieli nie poczuwa się do odpowiedzialności za obiekt i przeprowadzenie najmniejszych napraw $^{6}$ (fot. nr 5).

\footnotetext{
5 Według systematyki Kloeppla, o.c.

${ }^{6}$ W ryzalicie gniazdo mają pszczoły.
} 


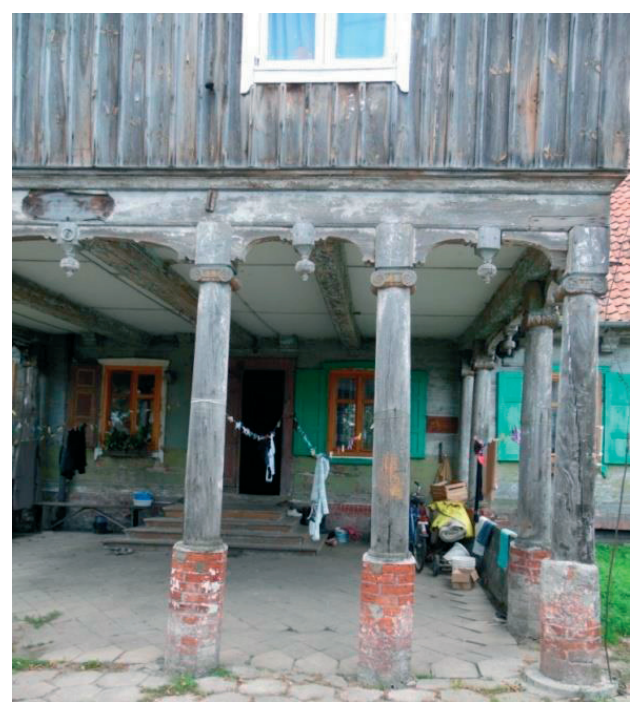

Fot. 5. Dom podcieniowy w Kępniewie. (fot. Autor)

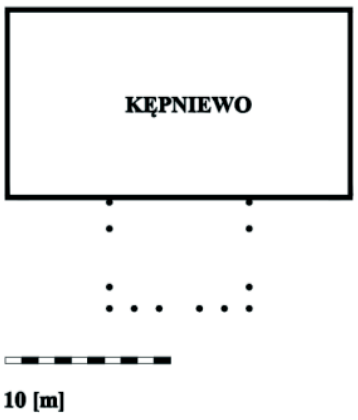

Rys. 2. Uproszczony rzut domu podcieniowego w Kępniewie. (opracowanie Autora)

3. Lasowice Wielkie nr 12 - dom podcieniowy z 1837 roku, typ III, z dobudowanym ryzalitem w roku 1881. Słupy drewniane o wysokości $230 \mathrm{~cm}$, przekrój kołowy o promieniu $17 \mathrm{~cm}$, proste bez ozdób, widoczne pęknięcia, słupy mają niewielki zielony nalot, osadzone na murowanych cokołach zakryte drewnianymi deskami, budynek niezamieszkały ${ }^{7}$ (fot. nr 6).

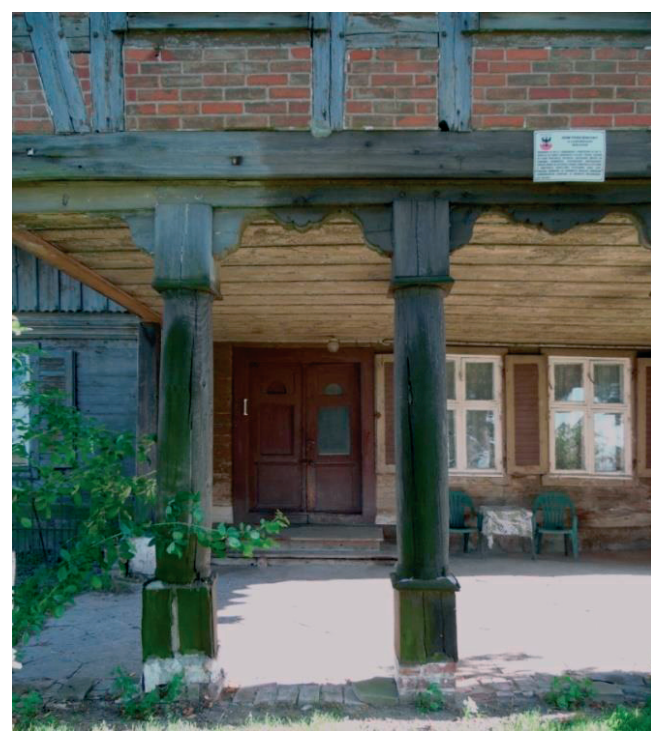

Fot. 6. Dom podcieniowy w Lasowicach Wielkich. (fot. Autor)

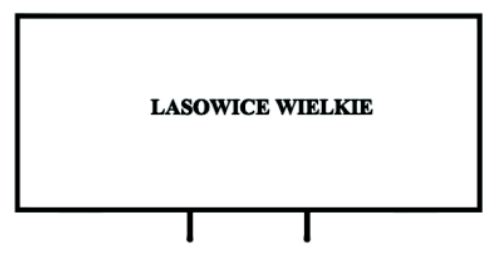

$10[\mathrm{~m}]$

Rys. 3. Uproszczony rzut domu podcieniowego w Lasowicach Wielkich. (opracowanie Autora)

\footnotetext{
7 Właściciel chce przeprowadzić generalny remont obiektu.
} 
4. Nowa Cerkiew nr 15/16 - dom podcieniowy z 1820 roku, typ III. Słupy drewniane o przekroju prostokątnym 28x32,5 cm, wysokość $285 \mathrm{~cm}$, proste bez zdobień, liczne drobne uszkodzenia mechaniczne, posadowione na kamieniach, u dołu podcieni widoczne ubytki spowodowane korozją biologiczną, nie stwierdzono zniszczeń wywołanych przez owady. Dom zamieszkały, podcień nieużytkowany, grozi zawaleniem. (fot. nr 7).

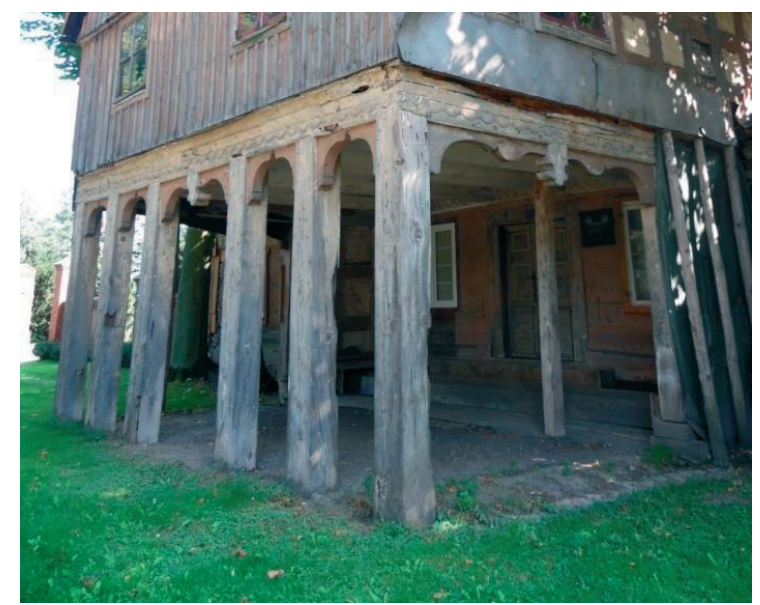

Fot. 7. Dom podcieniowy w Nowej Cerkwi. (fot. Autor)

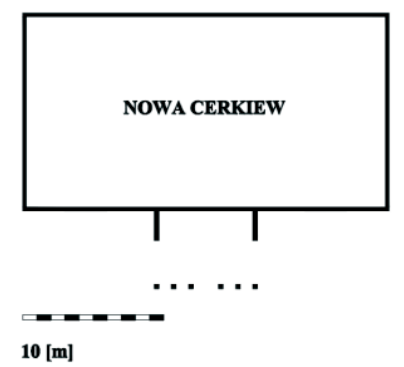

Rys. 4. Uproszczony rzut domu podcieniowego w Nowej Cerkwi. (opracowanie Autora)

5. Klecie nr 4 - dom podcieniowy z ok. 1750 roku, typ I. Słupy drewniane o wysokości $250 \mathrm{~cm}$, przekrój o wymiarach $28 \times 30 \mathrm{~cm}$, bez zdobień, kolumny posadowione na pojedynczych kamiennych głazach, liczne uszkodzenia, pęknięcia, widoczne ślady zniszczeń przez szkodniki, podstawy z ubytkami. Ogólny stan obiektu dostateczny, zamieszkały, w części frontowej od strony podcienia znajduje się wiejska świetlica (fot. nr 8). Brak informacji odnośnie wymiany wszystkich słupów w latach powojennych [18], [19], [20], [21], [22].

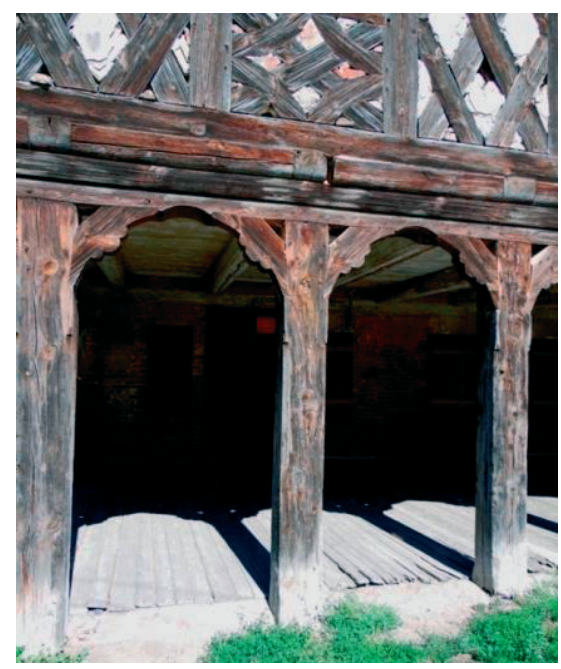

Fot. 8. Dom podcieniowy w Kleciu. (fot. Autor) 
6. Żuławki nr 32/33 - dom podcieniowy z 1797, typ III. Słupy drewniane dekorowane, posadowione na murowanym fundamencie, o wysokości $260 \mathrm{~cm}$ i promieniu w najmniejszym przekroju równym $14 \mathrm{~cm}$. Widoczne ubytki w podstawie kolumny, pęknięcia. Obiekt znajduje się blisko jezdni co niekorzystnie wpływa na jego stan techniczny (fot. nr 9). Brak informacji odnośnie wymiany słupów w latach powojennych [23], [24],[25].

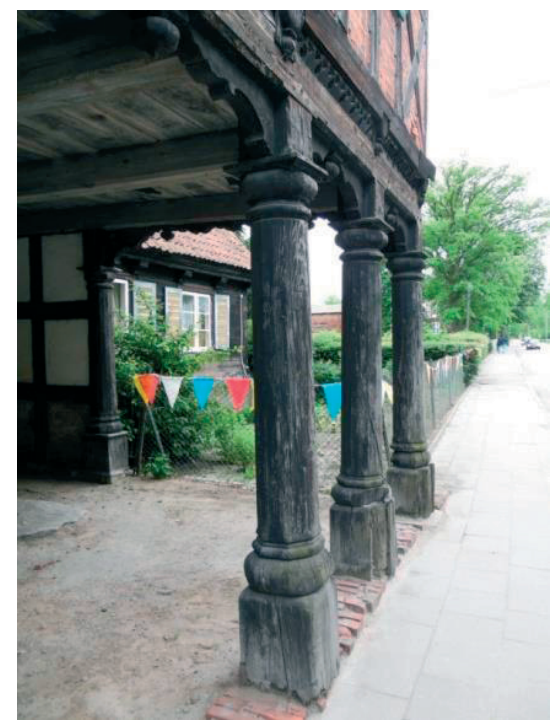

Fot. 9. Dom podcieniowy w Żuławkach. (fot. Autor)

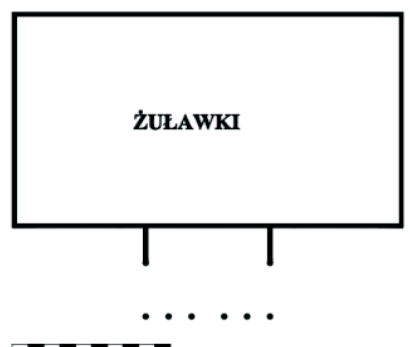

$10[\mathrm{~m}]$

7. Orłowo w PGR I - dom podcieniowy z 1802 roku, typ III, wybudowany przez Piotra Loewena, słupy dekorowane, wysokość $200 \mathrm{~cm}$, przekrój kołowy o promieniu 17,5 cm, słup posadowiony na ceglanym otynkowanym cokole, widoczne pęknięcia, brak korozji biologicznej, obiekt niezamieszkały (fot. nr 10). Brak informacji odnośnie wymiany słupów w latach powojennych [26], [27].

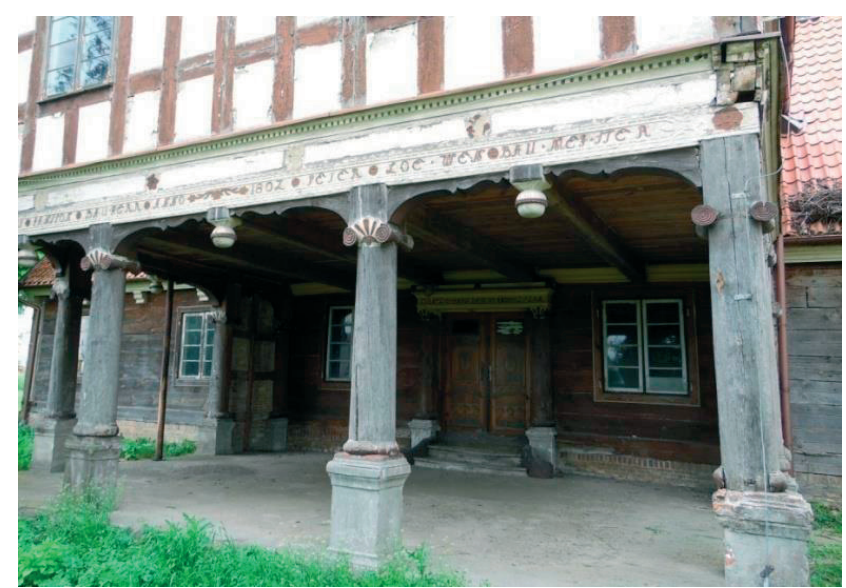

Fot. 10. Dom podcieniowy w Orłowie. (fot. Autor) 
Ocena stanu zachowania konstrukcji poszczególnych podcieni odbyła się na podstawie wykonanych przez autora:

- wizji lokalnych w okresie od maja do września 2016 roku, w trakcie których dokonano pomiarów wysokości i przekrojów poprzecznych słupów oraz innych wymiarów potrzebnych do oszacowania ciężaru ryzalitu opartego na słupach. Szczegółowe dane (długości, szerokości, wysokości) wykorzystane w obliczeniach, zostały zebrane i przedstawione w tabeli (Tab. 2), autor dodatkowo zamieścił w tekście uproszczone rzuty wymiarów zewnętrznych pięciu domów podcieniowych (rys.1$5)^{8}$;

- analizy dostępnej dokumentacji historyczno-konserwatorskiej oraz technicznej informującej o przeprowadzonych pracach remontowo-budowlanych ${ }^{9}$;

- wywiadu wśród właścicieli obiektów;

- dokumentacji fotograficznej pokazującej aktualny stan elementów konstrukcyjnych.

\section{Obliczenia statyczno wytrzymałościowe}

Obliczenia nośności na ściskanie drewnianych słupów zostały wykonane przez autora w oparciu o normę PN-EN 1995-1-1 Konstrukcje drewniane, zwana Eurokodem 5. została wprowadzona w Polsce w 2010 roku razem z innymi normami technicznym, przyjętymi w ramach ujednolicenia procesów projektowania w Unii Europejskiej. Do obliczeń wykorzystano wzory z rozdziału 6.1.4 Ściskanie wzdłuż włókien oraz 6.3 Stateczność elementów [28]. Zaprezentowane poniżej obliczenia są dla słupów domu podcieniowego w miejscowości Bystrze. Analogiczny tok postępowania wykonano dla pozostałych obiektów. Wyniki analizy zostały zebrane i przedstawione w tabeli nr 1 (Tab. 1).

Wysokość słupa drewnianego $H=215 \mathrm{~cm}$.

Przyjęto pręt podparty przegubowo (drewno z wiekiem zsycha się, połączenia ciesielskie ulegają poluzowaniu, podstawa słupa nie ma sztywnego połączenia z fundamentem), stąd też długość wyboczeniowa:

$$
l_{w}=\mu l=1 \cdot 215 \mathrm{~cm}=215,00 \mathrm{~cm}
$$

Należy również dodać, iż w trakcie pomiarów terenowych nie stwierdzono znacznych przemieszczeń i odchyleń od pionu drewnianych słupów, w górnej części i podstawie elementu, które mogłyby wpłynąć na nośność. Dodatkowo warto nadmienić, iż każdy słup już na etapie wykonywania obliczeń ma założone niewielkie odchylenie i mimośrodowe przyłożenie siły od obciążenia [29].

Zmierzony obwód słupa to $110 \mathrm{~cm}$, jego promień jest równy $r=110 /(2 \cdot 3,13)=$ $17,50 \mathrm{~cm}$. Analizowane słupy drewniane posiadają widoczne niewielkie ubytki, pęknięcia oraz ślady korozji biologicznej czy uszkodzeń wywołanych przez owady. Powoduje to konieczność zmniejszenia przekroju poprzecznego słupa w dalszych obliczeniach. W zależności od wielkości ubytków, pęknięć można przyjąć zmniejszenie przekroju słupa

\footnotetext{
${ }^{8} \mathrm{Na}$ rzutach nie umieszczono szczegółowych planów wnętrz domów podcieniowych, podziałów na poszczególne pomieszczenia, ponieważ nie było to celem pomiarów wykonywanych przez Autora na potrzeby artykułu. Szkice mają charakter poglądowy, pokazujący ilość słupów oraz usytuowanie podcienia.

${ }^{9}$ Dokumentacja budowlano-konserwatorska znajduje się w zasobach Narodowego Instytutu Dziedzictwa w Gdańsku (NID). Poszczególne pozycje podane są przy opisach analizowanych obiektów. Celem kwerendy archiwalnej było ustalenie stopnia ingerencji lub ich brak, w konstrukcję zabytkowych obiektów.
} 
w zakresie od 2 do 5\% [30]. Praktyka inżynierska obecnie stosowana dopuszcza w niektórych przypadkach zmniejszenie przekroju nawet do 50\% [31]. Z doświadczeń zawodowych autora $^{10}$ wynika, że całościowy stan destrukcji drewna, w obiektach zabytkowych nie zawsze jest widoczny, niekiedy skalę zniszczeń można określić dopiero w momencie rozebrania części obiektu lub dokonania odkrywek. W projektowaniu konstrukcji, ze względu na bezpieczeństwo, należy założyć niekorzystniejszą sytuację, większe zniszczenia. Stąd też na potrzeby artykułu przyjęto zmniejszenie przekroju o $10 \%$.

Pole przekroju po uwzględnieniu pęknięć i ubytków:

$$
A_{d}=0,9 \cdot 3,14 \cdot 17,5^{2}=867,04 \mathrm{~cm}^{2}
$$

Obecnie na rynku polskim dostępne jest drewno klasy C20-C24, dlatego w projektowaniu konstrukcji jest ono powszechnie wykorzystywane [32]. Jest to nowy materiał konstrukcyjny bez uszkodzeń i innych defektów, posiadający pełną zakładaną nośność. W przypadku elementów starszych, zabytkowych, poddanych wieloletniej ekspozycji na zewnętrzne czynniki atmosferyczne oraz możliwości powstawania innych uszkodzeń, również ze względów bezpieczeństwa należy założyć niższą wytrzymałość. Do dalszych obliczeń przyjęto klasę drewna litego iglastego C16. Wartości parametrów wytrzymałościowych przyjęte na podstawie tabeli z PN - EN 338:2011

Wytrzymałość na ściskanie drewna wzdłuż włókien $f_{c, 0, k}=17 \mathrm{MPa}$

$5 \%$ kwantyl modułu sprężystości wzdłuż włókien $\mathrm{E}_{0,05}=5400 \mathrm{MPa}$

$\gamma_{m}=1,30$ dla drewna litego (tablica 2.3)

$k_{\text {mod }}=0,65$ przyjęty dla klasy użytkowania trzeciej, wartość dla obciążeń średniotrwałych, przyjęta według tablicy 3.1. Obliczeniowa wartość na ściskanie wzdłuż włókien:

$$
f_{c, 0, d}=k_{\mathrm{mod}} \cdot \frac{f_{c, o, k}}{\gamma_{m}}=0,65 \cdot \frac{17}{1,3}=8,50 \mathrm{MPa}
$$

Moment bezwładności:

$$
I_{z}=I_{y}=\frac{\pi \times r^{4}}{4}=\frac{3,14 \times 17,5^{3}}{4}=73892,75 \mathrm{~cm}^{4}
$$

Dla słupów o przekroju prostokątnym, ze względu na jednakową długość wyboczeniową na kierunku $y$ i $z$, obliczenia nośności słupa wykonano z uwzględnieniem mniej korzystnego kierunku pracy (z mniejszym momentem bezwładności).

Promień bezwładności:

$$
i_{y}=\sqrt{\frac{I_{y}}{A_{d}}}=\sqrt{\frac{73892,75}{867,04}}=9,23 \mathrm{~cm}
$$

Smukłość słupa:

$$
\lambda_{y}=\frac{l_{y}}{i_{y}}=\frac{215}{9,23}=23,29[-]
$$

10 Autor artykułu pracował przy remoncie ścian ryglowych zabytkowego kościoła św. Mikołaja w Cyganku na Żuławach (maj - sierpień 2015 r.), na stanowisku inżyniera budowy, w Polskie Pracownie Konserwacji Zabytków S.A. w Warszawie, oddział Gdańsk. 
Smukłość względna:

$$
\begin{aligned}
& \lambda_{r e l, y}=\frac{\lambda_{y}}{\pi} \sqrt{\frac{\mathrm{f}_{\mathrm{c}, 0, \mathrm{k}}}{\mathrm{E}_{0,05}}}=\frac{23,29}{3,14} \cdot \sqrt{\frac{17}{54000}}=0,42>0,3, \text { należy uwzględnić wyboczenie (6.21) } \\
& k_{y}=0,5\left[1+\beta_{c}\left(\lambda_{\text {rel, }, y}-0,3\right)+\lambda_{\text {rel, }, y}{ }^{2}\right]=0,5 \cdot\left[1+0,2 \cdot(0,42-0,3)+0,42^{2}\right]=0,60(6.28) \\
& \beta_{c}=0,2 \text { dla drewna litego }(6.29) \\
& k_{c, y}=\frac{1}{k_{y}+{\sqrt{k_{y}^{2}-\lambda_{r e l, y}^{2}}}^{2}}=\frac{1}{0,60+\sqrt{0,60^{2}-0,42^{2}}}=0,97
\end{aligned}
$$

Warunek dla naprężeń:

$$
\begin{aligned}
& \frac{\sigma_{c, 0, d}}{k_{c, z} f_{c, 0, d}}<1,00(6.24) \\
& \sigma_{c, 0, d}=\frac{N}{A_{d}}<k_{c, z} f_{c, 0, d} \leftrightarrow N<A_{d} k_{c, z} f_{c, 0, d}
\end{aligned}
$$

Największa siła obliczeniowa ściskanego przekroju musi spełniać warunek:

$$
N<867,04 \cdot 0,97 \cdot 8,50 \mathrm{~N}
$$

Nośność słupa na ściskanie wynosi:

$$
N<716,95 \mathrm{kN}
$$

Interesującym zagadnieniem w odniesieniu do konserwacji zabytków, jest porównanie metod oceny nośności aktualnie stosowanych norm, z procedurami obliczeniowymi stosowanymi dawniej. Analizując archiwalną dokumentację techniczną oraz ekspertyzy budowlane $\mathrm{z}$ drugiej połowy $\mathrm{XX}$ wieku ${ }^{11}$ możemy zwrócić uwagę na prostotę obliczeń, stosowanie inżynierskich formuł i dobór odpowiednich współczynników z tabel. Do analizy tego samego problemu - określenia nośności zabytkowych słupów domów podcieniowych skorzystano ze starej normy PN-53/B-03150 - metoda stanów granicznych [33].

Wzór na dopuszczalne naprężenia:

$$
\sigma=\frac{P}{F \beta}<m R_{c o}
$$

po przekształceniu otrzymujemy wzór na dopuszczalną siłę, nośność słupa:

$$
P=F \beta m R_{c o}
$$

$F$ - pole przekroju słupa, $\beta$-współczynnik wyboczenia, odczytany z tabeli z normy PN53/B-03150, zależny od smukłości, $m$ - współczynnik warunków pracy przy wyboczeniu, $R_{c o}$ - wytrzymałość obliczeniowa na ściskanie, wg tablicy 3-3 normy.

Obliczenia dla słupa domu podcieniowego w Bystrzu:

\footnotetext{
11 Narodowy Instytut Dziedzictwa (NID) w Gdańsku posiada dokumentację przejętą od Przedsiębiorstwa Państwowego Pracowni Konserwacji Zabytków, oddział Gdańsk. Materiały obejmują inwentaryzacje architektoniczno-konserwatorskie, sprawozdania z prac remontowych, ekspertyzy budowlane domów podcieniowych od lat pięćdziesiątych do osiemdziesiątych XX wieku. Całość dokumentacji została przekazana w latach 1995-2001 na polecenie Ministra Kultury i Sztuki.
} 


$$
\begin{aligned}
& F=0,9 \cdot 3,14 \cdot 17,5^{2}=867,04 \mathrm{~cm}^{4} \\
& i_{y}=9,23 \mathrm{~cm} \\
& \lambda_{y}=\frac{l_{y}}{i_{y}}=\frac{215}{9,23}=23,29[-] \\
& \beta=0,9567 \text { wartość otrzymana } \mathrm{z} \text { interpolacji liniowej, } \\
& m=1,0 \text { dla elementów ściskanych, } \\
& R_{c o}=130 \frac{\mathrm{kG}}{\mathrm{cm}^{2}}=12,74 \mathrm{MPa} \\
& P=867,04 \cdot 0,9567 \cdot 1,0 \cdot 12,74 \cdot 10^{-1}=1056,93 \mathrm{kN}
\end{aligned}
$$

Analogiczne obliczenia wykonano dla pozostałych przypadków. Wyniki przedstawiono w tabeli nr 1 .

Tabela 1. Zestawienie nośności słupów wg PN EN 1995 1-1 i PN B -53/B-03 150.

\begin{tabular}{llcccc}
\hline \multirow{2}{*}{$1 \mathrm{p}$} & \multirow{2}{*}{ miejscowość } & \multicolumn{2}{c}{ nośność słupa [kN] } & \multirow{2}{*}{ różnica $[\mathrm{kN}]$} & różnica [\%] \\
\cline { 2 - 4 } 1. & Bystrze & 716,95 & 1056,93 & 339,98 & 32,17 \\
\hline 2. & Kępniewo & 454,29 & 673,94 & 219,65 & 32,59 \\
\hline 3. & Klecie & 605,91 & 898,26 & 292,35 & 32,55 \\
\hline 4. & Lasowice Wielkie & 670,84 & 990,36 & 319,52 & 32,26 \\
\hline 5. & Nowa Cerkiew & 639,47 & 948,77 & 309,29 & 32,60 \\
\hline 6. & Orłowo & 722,23 & 1064,11 & 341,88 & 32,13 \\
\hline 7. & Żuławki & 450,04 & 668,07 & 218,02 & 32,63 \\
\hline & & & średnia: & 32,42 \\
\hline
\end{tabular}

Drewniane słupy w żuławskich domach podcieniowych przenoszą głównie ciężar własny ryzalitu (wystawki) oraz obciążenia użytkowe. Na podstawie pomiarów i przyjęciu typowych rozwiązań elementów konstrukcyjnych (strop, ściany, dach) oszacowano ich ciężary obliczeniowe. Połowa obciążeń przechodzi na ścianę domu, druga na ramę ze słupami. Obliczenia wykonano tylko dla domów typu III. Celem kalkulacji jest ustalenie jaką część całkowitego ciężaru ryzalitu przenosi pojedynczy słup podcienia. Rozstaw osiowy słupów w ramie tworzącej podcień jest stały, tylko w środku jest nieco szerszy (stanowi to dojście do głównego wejścia domu). Fakt ten powoduje różnice w wartości sił normalnych w słupach, lecz są one niewielkie. Celem artykułu jest analiza uproszona, dlatego przyjęto, że każdy słup w przybliżeniu przenosi ten sam ciężar. Zestawienie wartości sił zawarto $\mathrm{W}$ tabeli $\mathrm{nr} 2$ (Tab. 2). W konstrukcji podcienia typu III, pojawiają się również dodatkowe słupy boczne ${ }^{12}$, zwężające światło przejazdu pod podcieniem, nie pełnią one roli konstrukcyjnej, są elementami ozdobnymi [34].

Przyjęto następujące wartości w zaokrągleniu [35]:

12 Warto zwrócić uwagę, że w domach podcieniowych w Bystrzu, Lasowicach Wielkich, Nowej Cerkwi, Żuławkach, Orłowie przestrzeń między słupami bocznymi, a ścianą budynku jest wypełniona murem o konstrukcji ryglowej (fot. 7,9,10), (rys. 1,3,4,5). 
- odciążenie ze stropu drewnianego: $3,50 \mathrm{kN} / \mathrm{m}^{2}$

- ciężar muru $16,25 \mathrm{kN} / \mathrm{m}^{3}$

- obciążenie z dachu $1,50 \mathrm{kN} / \mathrm{m}^{2}$

Tabela 2. Zestawienie ciężarów przypadających na słupy.

\begin{tabular}{|c|c|c|c|c|c|}
\hline \multirow[b]{2}{*}{ miejscowość: } & 1 & 2 & 3 & 4 & 5 \\
\hline & Bystrze & Kępniewo & $\begin{array}{l}\text { Lasowice } \\
\text { Wielkie }\end{array}$ & $\begin{array}{l}\text { Nowa } \\
\text { Cerkiew }\end{array}$ & Żuławki \\
\hline długość ryzalitu [m] & 7,67 & 8,37 & 7,78 & 7,36 & 7,57 \\
\hline szerokość ryzalitu $[\mathrm{m}]$ & 6,21 & 6,57 & 5,98 & 5,53 & 5,34 \\
\hline wysokość ściany ryzalitu [m] & 2,50 & 2,50 & 2,60 & 3,00 & 2,60 \\
\hline wysokość ściany szczytowej ryzalitu [m] & 5,00 & 5,00 & 5,20 & 6,25 & 5,20 \\
\hline powierzchnia ścian $\left[\mathrm{m}^{2}\right]$ gr $30 \mathrm{~cm}$ & 59,82 & 70,50 & 69,05 & 72,00 & 64,27 \\
\hline powierzchnia stropu $\left[\mathrm{m}^{2}\right]$ & 47,65 & 54,96 & 46,56 & 40,70 & 40,40 \\
\hline powierzchnia dachu $\left[\mathrm{m}^{2}\right]$ & 53,41 & 52,53 & 54,43 & 50,32 & 47,50 \\
\hline $\begin{array}{l}\text { obciazżenie ze stropu x } 2[\mathrm{kN}] \text { (ryzalit ma dwa } \\
\text { stropy, w swojej konstrukcji) }\end{array}$ & 333,55 & 384,72 & 325,95 & 284,91 & 282,78 \\
\hline obciążenie ze ścian [kN] & 291,64 & 343,67 & 336,64 & 351,02 & 313,34 \\
\hline obciążenie z dachu [kN] & 80,12 & 78,80 & 81,65 & 75,48 & 71,24 \\
\hline suma $[\mathrm{kN}]:$ & 705,31 & 807,19 & 744,23 & 711,41 & 667,36 \\
\hline $\begin{array}{l}\text { połowa obciążenia przypadająca na ramę ze } \\
\text { słupami }[\mathrm{kN}] \text { : }\end{array}$ & 352,66 & 403,59 & 372,12 & 355,70 & 333,68 \\
\hline ilość słupów w ramie ryzalitu: & 6 & 6 & 6 & 6 & 6 \\
\hline nośność słupa $[\mathrm{kN}]$ przekrój osłabiony wg PN EN & 716,95 & 454,29 & 670,84 & 639,47 & 450,04 \\
\hline $\begin{array}{l}\text { siła przypadająca na jeden słup }[\mathrm{kN}] \\
\end{array}$ & 58,78 & 67,27 & 62,02 & 59,28 & 55,61 \\
\hline $\begin{array}{l}\text { siła przypadająca na jeden słup w odniesieniu do } \\
\text { jego nośności [\%] }\end{array}$ & 8,20 & 14,81 & 9,25 & 9,27 & 12,36 \\
\hline
\end{tabular}

\section{Wnioski}

Przeanalizowane podcienia mimo uszkodzeń wykazują dużą nośność na ściskanie w zakresie 450,04 -716,95 kN. Zachowała się ona dzięki znacznym wymiarom przekrojów poprzecznych, tych elementów. Na uwagę zasługują wyniki porównania sposobu obliczania maksymalnej siły w ściskanych słupach, według obecnie obowiązującej PN-EN 1995-1-1 i starej polskiej normy PN-53/B-03150, wykazujące, że metody obliczeniowe wówczas stosowane były skuteczne. Różnica nośności w obliczeniach wynosi średnio 32,42\%. Według normy PN-53/B-03150 słupy mają też większą nośność. Wynika to głównie z różnych wartości przyjętej do obliczeń wytrzymałości obliczeniowej drewna, jaką narzucają normy. Dodatkowo norma PN-53/B-03150 wskazuje znacznie prostszy algorytm obliczeń. Zachowane słupy mimo utraty części nośności spowodowanej wiekiem i zmniejszeniem przekroju, nadal spełniają swoją rolę konstrukcyjną. Ryzality domów nie wykazują znacznych ugięć, ani ryzyka katastrofy, spowodowanej uszkodzeniem drewnianych podcieni. Przeprowadzone obliczenia wykazują, że tylko niewielka część nośności słupa na ściskanie jest wykorzystywana (przedział od 8,20-14,81\%). Informacja ta jest ważna z punktu widzenia zasad prawidłowego postępowania konserwatorskiego, nakazujących zachowanie jak największej ilości autentycznych elementów zabytku oraz zminimalizowa- 
nie ingerencji w strukturę obiektu. Otrzymane wyniki obliczeń wykazują, że oryginalne słupy po zakończeniu prac mogą ponownie zostać wbudowane w swoje pierwotne miejsce i dalej pełnić rolę konstrukcyjną, bez konieczności ich wymiany na nowe. Mimo tego, wymagają, one zarówno ochrony (głównie przed szkodliwymi czynnikami biologicznymi), jak również prac konserwatorskich lub w niektórych przypadkach napraw. Przedstawiona analiza miała na celu zwrócenie uwagi na interdyscyplinarny charakter działań konserwatorskich. W trakcie całego procesu ich projektowania i realizacji należy uwzględnić wiedzę i doświadczenie z kilku różnych dziedzin, takich jak inżynieria (projektowanie konstrukcji drewnianych), konserwacja zabytków oraz historia architektury. Ich wspólnym i nadrzędnym celem powinno być zawsze prawidłowe zachowanie zabytkowych obiektów dla przyszłych pokoleń.

\section{Podziękowania}

Autor serdecznie dziękuje Panu dr inż. Antoniemu Kapuścińskiemu, za inspirujące uwagi i cenne wskazówki naukowe, których udzielił mi podczas pracy nad tekstem.

\section{Literatura}

1. Tłoczek I. Dom mieszkalny na polskiej wsi. Państwowe Wydawnictwo Naukowe, Warszawa 1985r, s.101-108.

2. Kopkowicz F. Ciesielstwo polskie. Arkady, Warszawa 1958r, s.66-74.

3. Koperska-Kośmicka M. Żuławskie domy podcieniowe. Przyczyny degradacji i problematyka konserwatorska zabytkowych struktur architektonicznych w środowisku kulturowym Delty Wisty. Rozprawa doktorska. Gdańsk 2014r. s. 124-132.

4. Kloeppel O. Die bauerliche Haus-, Hof - Und Siedlungsanlage im Weichsel - Nogat Delta. Danzig 1924., s.123-127.

5. Archiwum Państwowe w Gdańsku, sygnatura: 300, MP-511.

6. Heise J. Die Bau Und Kunstdenkmaler der Provinz Westpreussen, H.11 Landkreis. Danzig, Comissions - Verlag von Th. Berling. Danzig $1884-1887$.

7. Stankiewicz J. Zabytki budownictwa i architektury na Żuławach. Rocznik Gdański, t. XV/XVI. Gdańskie Towarzystwo Naukowe, Gdańsk 1956/1957, s. 511-522.

8. Tłoczek I. Dom mieszkalny..., op. cit., s. 109-110.

9. Koperska-Kośmicka M. Żuławskie domy podcieniowe... op. cit., s. 185, 213-215.

10. Neuhaus H. Budownictwo drewniane. Polskie Wydawnictwo Techniczne, Rzeszów 2004r., s 17.

11. Hoła J., Pietraszek P. Budynki o konstrukcji drewnianej. w: Budownictwo Ogólne - konstrukcje budynków tom 4. Buczkowski W. (red.), Arkady, Warszawa 2009r., s.100-101.

12. Baszeń M., Żakowicz A. Wpływ zmian materiałowych i geometrii konstrukcji drewnianych na rozkład sit wewnętrznych. Źródło: http://www.biswbis.pb.edu.pl/2011_01/014.pdf, data pobrania: 10.03.2017r.

13. Rudziński L. Konstrukcje drewniane, naprawy, wzmocnienia, przykłady obliczeń. Wydawnictwo Politechniki Świętokrzyskiej w Kielcach, Kielce 2010r., s. 149.

14. Kolendowicz T. Mechanika budowli dla architektów. Arkady, Warszawa 1993r., s. 25-29.

15. Przewłocki J., Górski J. Podstawy mechaniki budowli. Arkady, Warszawa 2006r. s.204-208.

16. Rejestr zabytków województwa pomorskiego, źródło:

http://www.nid.pl/pl/Informacje_ogolne/Zabytki_w_Polsce/rejestr-zabytkow/zestawieniazabytkow-nieruchomych/ data pobrania: 05.01.2016r.

17. Rejestr zabytków województwa warmińsko mazurskiego, źródło:

http://www.nid.pl/pl/Informacje_ogolne/Zabytki_w_Polsce/rejestr-zabytkow/zestawieniazabytkownieruchomych/ data pobrania: 05.01.2016r. 
18. Krzyżanowska K. Klecie. Dom podcieniowy. Dokumentacja historyczna. Gdańsk 1959 r. sygnatura NID: 00108.

19. Specht A. Klecie. Dom podcieniowy. Inwentaryzacja konserwatorska - przeskalowanie - skala 1 : 50. Gdańsk 1978 r., sygnatura NID: P/02928.

20. Specht A. Klecie. Dom podcieniowy. Inwentaryzacja konserwatorska. Gdańsk 1977 r., sygnatura NID: P/02400.

21. Specht A., Wołosewicz A. Klecie. Dom podcieniowy. Badania architektoniczne. T.I: Tekst $i$ rysunki. Gdańsk 1978 r., sygnatura NID: 00668/1.

22. Swierk Z. Klecie. Dom podcieniowy. Orzeczenie mykologiczno - budowlane. Gdańsk 1978 r., sygnatura NID: P/02551.

23. Hoffman B. Żuławki. Dom podcieniowy $n r 32$ i 33. Orzeczenie techniczne konstrukcyjne. Gdańsk 1980 r., sygnatura NID: P/02859.

24. Osiński A. Żuławki. [ Dom podcieniowy] Budynek mieszkalny nr 32 - 33. Ekspertyza techniczna - mykologiczna. Gdańsk 1980 r., sygnatura NID: P/02791.

25. Stankiewicz K. Żuławki. Dom podcieniowy nr 32 - 33. Inwentaryzacja konserwatorska. Gdańsk 1980 r., sygnatura NID: P/02749.

26. Domagała T. Orłowo. Dom podcieniowy " Orlowo I ". Sprawozdanie z przebiegu prac konserwatorskich ( 13.03 .1968 - 30.10.1968). Gdańsk 1968 r., sygnatura NID: ZN/3007.

27. Domagała T., Kołecki A. Orłowo. Dom podcieniowy "Orłowo I".Sprawozdanie z przebiegu prac konserwatorskich (13.III.1968 - 30.X.1968). Gdańsk 1968 r., sygnatura NID: 00106.

28. PN-EN 1995-1-1 Eurokod 5. Projektowanie konstrukcji drewnianych, Część 1-1: Postanowienia ogólne. Reguły ogólne i reguły dotyczące budynków. Polski Komitet Normalizacyjny, Warszawa 2010r.

29. Przewłocki J., Górski J. Podstawy..., op. cit., str. 205.

30. Rudziński L. Konstrukcje drewniane..., op. cit., str 30.

31. Bela A. Obliczenia statyczne dla oceny stanu zachowania ryglowej części kościoła p.w. św. Mikołaja w Cyganku - Żelichowie. Gdańsk, 2014., s. 3.

32. Kotwica E.I., Nożyński W. Konstrukcje drewniane - przykłady obliczeń. Stowarzyszenie producentów płyt drewnopochodnych w Polsce, Szczecin 2015 r., s.15.

33. Michniewicz W. Konstrukcje drewniane. Arkady, Warszawa 1958., s. 50, 91-98.

34. Stankiewicz J. Zabytki..., op. cit., s. 522.

35. Niedostatkiewicz M. Budownictwo Ogólne przykłady obliczeń. Wydawnictwo Politechniki Gdańskiej, Gdańsk 1999 r., s. 9, 42, 144.

\title{
The impact of maintenance on wood column capacity of the XVIIIth to XIXth century of arcaded houses from the $\dot{Z} u$ lawy region
}

\author{
Tomasz Zybala
}

\author{
Department of History, Theory of the Architecture and Conservation of Monuments, \\ Faculty of Architecture, Gdańsk University of Technology and \\ Faculty of Architecture and Design, Academy of Fine Arts in Gdansk. and \\ Faculty of Architecture, Sopot University of Applied Sciences. \\ e-mail:t.zybala7@gmail.com
}

\begin{abstract}
There have been many articles on architectural issues of arcaded houses from the Żuławy Region. None of them tackled the technical and conservation problems. The following article presents a part of the author's current research. It is the first attempt to demonstrate a static-strength analysis of selected historic wooden houses from Żuławy. It
\end{abstract}


demonstrates the maintenance state of those buildings and includes the description of the main strength features of timber as well as the calculation rules of column capacity in compliance with PN EN 1995-1-1 and PN-53/B-03150. The approximate static load transferred by wood columns was calculated. The article describes both main forms of the arcaded construction in Poland and its territorial range. Furthermore, the paper accounts for the purpose of using this solution in buildings and provides the main types of both structure and typology of arcaded houses in Żuławy Region as well as their historical progress and key characteristic features

Keywords: arcaded houses, wooden architecture, capacity of timber column. 